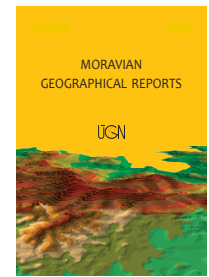

MORAVIAN GEOGRAPHICAL REPORTS

\title{
Rural identity and landscape aesthetics in exurbia: Some issues to resolve from a Central European perspective
}

\author{
Kristina JANEČKOVÁ MOLNÁROVÁ a *, Zuzana SKŘIVANOVÁ a \\ Ondřej KALIVODA ${ }^{\text {b }}$, Petr SKLENIČKA ${ }^{a}$
}

\begin{abstract}
Although perceptions of landscape aesthetics are currently attracting great research interest, some aspects of the topic have remained almost unexamined. This review highlights some less studied areas that are of particular importance for landscape management, with special focus on rapidly growing exurban areas. While the visual quality of the environment is undoubtedly one of the drivers that has been spurring the exurban development of rural settlements, much remains unknown about the perception of the visual quality of these settlements. Another pressing issue is the need to determine general principles of consensus formation concerning visual landscape preferences. This study concludes that in order to preserve the rural character of exurban landscapes, there is an urgent need to identify the aesthetic values that define the character of rural settlements and their importance to the stakeholder groups.
\end{abstract}

Key words: landscape perception, visual quality assessment, exurban landscapes, judgement variability, Central Europe

Article history: Received 2 June 2016; Accepted 6 December 2016; Published 31 March 2017

\section{Introduction: Rural identity in the context of the exurban settlement process}

In its physical aspect, rural identity is based on site characteristics (Ihatsu, 2005), which are continually influenced by all events occurring within a territory. Rural identity is therefore, at the best of times, in a very dynamic equilibrium. Recent rapid developments have raised concerns for the protection of rural identity (Foley and Scott, 2014; Taylor, 2011; Vorel et al., 2003), however, especially in places where the exurban settlement process is taking place. In the post-socialist countries of Central Europe (Northern Croatia, the Czech Republic, the former East Germany, Hungary, Poland, Slovakia and Slovenia), the erosion of rural identity by exurbanisation is being accelerated by a building boom following 50 years of repression under the communist regime (Maier, 1998), and aided by a 50-year long severance of the landowners' ties to their land (Sklenicka et al., 2014).

\subsection{The exurban settlement process}

The form of an exurban settlement process largely depends on the culturally and legally determined forms of settlement in the relevant area. In the USA, An et al. (2011) define exurban residential landscapes as "low-density settlements that are contiguous with metropolitan urbanised areas but disconnected from city services of sewer and water". In this context, LaGro (1998) notes that "residential development... routinely occurs beyond the boundaries of cities, villages and other incorporated communities". In the European context, exurban housing is usually built on the fringes of existing villages, taking advantage of the municipal amenities (where present), though often failing to accordingly contribute to these communities (Peltan, 2012).

In the post-socialist countries of Central Europe, the extent and the form of exurbanisation is determined by traditional settlement patterns, by policies implemented during the communist regime, and by land use policies adopted after the fall of the regime.

Traditional settlement patterns in the Central European countries date back to the late middle ages (Pánek and Tůma, 2009) and consist of relatively regularly distributed towns and villages with high settlement density, and also

\footnotetext{
${ }^{a}$ Dept. of Land Use and Improvement, Faculty of Environmental Sciences, Czech University of Life Sciences Prague, Czech Republic (*corresponding author: K. Janečková Molnárová, e-mail: janeckovak@fzp.czu.cz)

b Department of Applied Geoinformatics and Spatial Planning, Faculty of Environmental Sciences, Czech University of Life Sciences Prague, Czech Republic
} 
with open agricultural landscapes with a proportion of forest patches varying according to the natural conditions. The landscape outside settlements traditionally contained very few buildings. Where buildings were present outside of towns and villages, they mostly served agricultural purposes such as hay storage or shelter for animals. Residential houses were limited to special purposes such as hunting and gamekeeping (Löw and Míchal, 2003). The open landscape was often divided into long-strip fields belonging to the individual farms (Sklenicka et al, 2009; Houfkova et al., 2015). This distinctive settlement pattern along with the remnants of field patterns is crucial in defining the landscape character and identity of Central European rural landscapes (Löw and Míchal, 2003), and is in stark contrast to the dispersed land use pattern which is prevalent, for example, in North America (LaGro, 1998).

Under the socialist regimes $(1950 \mathrm{~s}-1980 \mathrm{~s}$, the exact years vary from country to country), land use planning was centralised and held a very strong position in the Soviet Block (Litwina and Pluta, 2015; Maier, 1998). Despite the many limitations of planning during this period, urban sprawl and exurban development were almost non-existent in the Central and East European countries (Nussl and Rink, 2005). After the fall of the communist regime, however, individual countries adopted a wide range of land use planning policies. Extreme cases are represented by the Czech Republic, on the one hand, and Poland, on the other. In the Czech Republic, the legal measures regulating sprawl and exurban development are relatively strict, and are strongly enforced. Building Act No. 183/2006 requires detailed land-use plans to be drawn up for each municipality. These plans, which regulate land use both in the built-up area and in the surrounding open space, ensure the continuance of the traditional settlement pattern of incorporated municipalities, though it does not prevent an over-intensive exurban settlement process. Moreover, larger developments in the rural areas are subject to Visual Impact Assessment (Vorel et al., 2003), which is defined in the Nature Protection Act No. 114/1992 Sb.

In contrast, the Polish Planning Act No. 80/2003 cancelled the obligation to make local land-use plans. Consequently, all Polish land can be freely developed, provided that a neighbouring plot is developed with housing (however, 'neighbourhood' is not further defined in the Act), there is access by a public road, and no other law is violated (e.g. environmental restrictions) (Halleux et al., 2012). While the consequences of this provision have begun to make their mark in the Polish landscape (Kurek et al., 2015), both current European authors (Sklenicka et al., 2013; Špulerová et al., 2013; Nuga et al., 2015) and long-term experience from other parts of the world, especially North America (Brabec, 2001; LaGro, 1994; McHarg and Mumford, 1969) warn against unregulated development of rural areas.

The exurban settlement process is largely driven by incoming residents seeking amenities such as proximity to landscapes of high natural (Ryan, 2002) and aesthetic value (Gosnell and Abrams, 2011), or privacy (Taylor, 2011). Studies of the economic impact of amenity migration (e.g. Carruthers and Vias, 2005), however, describe negative impacts of this migration, and subsequent changes in land use, on the scenic quality of the landscape that originally attracted the exurbanites (Sullivan, 1994; Taylor, 2011). Other studies (Hurley and Walker, 2004 Walker and Fortmann, 2003) note that where this is the case, the exurbanites tend to control the use of natural amenity areas, disrupting socio-political relationships in these areas.
Hence, an influx of new inhabitants often results in the disruption or even destruction of rural identity (Ryan, 2002) and landscape character. In contrast, Gosnell and Abrams (2011) conclude that receiving communities can benefit from changes associated with newcomers, and that the increased human capital and diversity of values can create new opportunities for the continuation of rural communities.

\subsection{Rural landscapes and their identity}

The rural character of a landscape has traditionally been defined by the predominant use of the landscape for food and fibre production (Löw and Míchal, 2003; Tilt et al., 2007; Thorbeck, 2012). But present-day rural landscapes are difficult to characterise with simple generalisations (Marcouiller et al., 2001). Some definitions focus on the remoteness of the landscape and the size of the population (e.g. USDA, 2004), while others emphasise economic structure and income-generating activities (Lapping et al., 1989). Arendt et al. (1994) state that a rural character is determined both by the physical characteristics of a place and by its sense of community. Hart (1998) draws attention to the importance of land division systems in determining rural character, illustrating the differences between English rural landscapes with their cluster villages, and American landscapes with their predominantly dispersed rural settlement. Notwithstanding these ambiguities, rural character has remained an important value in people's assessment of landscapes (Vorel et al., 2003; Walker and Ryan, 2008).

In order to preserve the rural character of places where the exurban settlement process is taking place, it is necessary first to find a way to define the important characteristics of rural identity. The role of individual architectural and landscape features in defining this identity has been described in detail in a large number of ethnographic and architectural studies (e.g. Eben Saleh, 2001; Purcell and Nasar, 1992). Moreover, rural identity is also strongly interconnected with the aesthetic quality of rural settlements and the surrounding open landscape. It is determined by relationships among these features (Frederick, 2007), as well as by the relationship between people and the physical environment (Bourassa, 1988). As was shown in a study by Hägerhall (2001), aesthetically valuable landscapes manifest stronger identity, as they evoke clear and precise mental images. This aspect of rural identity is of considerable complexity.

The importance of an aesthetically valuable environment to the well-being of humankind and society has been emphasised in a number of studies. Although these studies mostly focus on the landscape outside settlements, their results may be indicative of the values of aesthetic quality in rural and exurban landscapes. Kates (1967), Kurdoglu and Kurdoglu (2010) and Tveit (2009) maintain that an aesthetically valuable environment has a significant impact on people's well-being. According to Jessel (2006), the aesthetic quality of landscapes forms a substantial part of the cultural heritage. Florida et al. (2010) have shown that the visual aesthetic quality of a landscape is important for the overall contentment of the local community. Howley et al. (2012) found that there is broad public support for conserving the traditional rural landscape, as expressed by willingness to pay for agricultural activities that contribute to its protection. Last but not least, this quality is important for the tourist trade (Ewald, 2001). Protection of the visual aesthetic quality of a landscape may therefore be considered in the public interest. 
On the diverse and rapidly evolving stage of current Central European landscapes, the protection of rural identity has become an urgent but increasingly complex issue. Experience from countries where similar processes started earlier can be helpful in avoiding the repetition of mistakes that have already been made elsewhere. The aim of this research project is therefore to review existing literature on rural identity and landscape aesthetics from the standpoint of the rural landscape, and to lay the groundwork for more effective protection of the rural identity of Central European farming landscapes, especially in the context of exurban settlement.

\section{Basic approaches to identifying the visual aesthetic qualities of landscapes}

Two basic approaches to the assessment of visual aesthetic qualities of landscapes have been established in recent decades: an approach based on expert evaluations; and an approach based on evaluations by the broader public. Both of these methods are mainly used for assessing landscapes outside settlements. They may also be used, however, for assessing settlements, inasmuch as a settlement is an integral part of a landscape. The expert-based approach works on the assumption that the aesthetic qualities of a landscape are independent of the observer (i.e. that the aesthetic value is an intrinsic quality of the landscape). Visual aesthetic qualities are then examined by identifying and quantifying landscape elements and characteristics with known aesthetic effects (e.g. Daniel, 2001; Jessel, 2006). The assessment is performed by experts, who assess a landscape on the basis of their own experience and defined criteria, which are usually grounded in general methodologies (Löw and Míchal, 2003; Swanwick and Land Use Consultants, 2002; USDA, 1995; Vorel et al., 2003), or are defined by the experts themselves. In any case, however, the criteria that are used should be based on previous extensive research that has proven their validity. Diverse criteria for visual aesthetic quality assessment (i.e. landscape elements and characteristics) are reported by many contributors, but such criteria are usually divided into groups of natural and cultural elements (Ryan, 2002).

In contrast, the approach based on evaluations by the broader public, also called perception-based assessment (Daniel, 2001; Frantál et al., 2016), is the outcome of a subjective approach, which considers aesthetic qualities to be a product of human perception (Lothian, 1999). Particular landscape elements and characteristics are regarded as stimuli that induce relevant psychological responses (i.e. a sensory perception and/or a perception arising from cognition) (Daniel, 2001). In this type of assessment, respondents within a sample area are asked to express their preferences for different landscape scenes. The basic issues addressed by studies of this type include the connection between visual preferences and scenic beauty (e.g. Clay and Smidt, 2004; De Val de la Fuente et al., 2006; Dramstad et al., 2006), or the differences in preferences for different landscape scenes (e.g. Arriaza et al., 2004; Van den Berg and Koole, 2006). Visual preferences are often assessed using open or structured interviews (e.g. Coeterier, 1996), or photo-based sorting procedures (e.g. Fyhri et al., 2009). Some studies use landscape evaluation in situ (e. g. Dearden, 1981). A number of authors, however, have found that this method can be replaced effectively by an evaluation based on landscape photographs (e.g. Palmer and Hoffman, 2001; Stamps, 1990; Stewart et al., 1984).
The approach based on evaluations by the broader public is more demanding than an expert-based approach in terms of time and money. But a perception-based assessment provides deeper knowledge about the causes and the stratification of the aesthetic preferences. Expert-based assessment usually results in landscapes being divided into just three categories: landscapes with low, medium and high aesthetic quality (Daniel, 2001). Moreover, the reliability and the validity of perception-based assessments are verifiable more easily, using statistical methods, than an expert-based assessment. Perception-based assessments are therefore most often used for scientific purposes.

In landscape management, expert-based assessment is widely used for determining the visual aesthetic qualities of a landscape (Ode et al., 2009). This approach benefits from low costs and low time demands. When based on welldefined criteria, expert-based assessment is sufficiently reliable and, at the same time, provides a complex insight into the character of a landscape. If, however, the criteria are poorly defined and are based purely on the experience of the experts, the results may not be reliable (Clay and Smidt, 2004). As Daniel (2001) points out, an important role of perception-based assessments is to diagnose pathological preferences for aesthetic qualities of landscape if these are inconsistent with other important values, such as values of an ecological, cultural or historical nature.

Expert-based assessment should therefore build on findings from perception-based research, through which factors driving the aesthetic perception of the wider public can be identified.

\section{Factors influencing the aesthetic perception of landscapes}

A rural landscape comprises a unique mix of natural and cultural values (Ryan, 2002). Even as landscape mediates our perception of the world, it also is a means by which we actively influence the world (Jorgensen, 2011). In recent decades, therefore, researchers have been prompted make a closer study of landscape aesthetic qualities.

From the theoretical point of view, Bourassa (1988) identified two principles of landscape aesthetics: the biological and the cultural. According to the biological principle, the highest aesthetic value is attributed to landscapes which appear to offer natural amenities such as prospect and refuge, whereas the cultural principle accentuates the aspect of cultural identity. Natural landscapes are experienced largely in biological mode, whereas urban landscapes are experienced primarily in cultural mode (Bourassa, 1990). Nassauer (1995) argues that while this theory accounts for some part of the empirical evidence, in many cases it is insufficient. Nassauer proceeds to outline four groups of theories explaining the formation of human preference for landscape: biological theories, information-processing theories, transactional theories and behavioural theories. She argues that behavioural theories, which emphasise the role of people as actors making landscapes, are the most useful in explaining people's landscape preferences.

Twentieth century research often used scenic quality as the measure of the attractiveness of a landscape (Tab. 1). Reflecting this research, a widely-used methodology presented in Landscape Aesthetics - A Handbook for Scenery Management (USDA, 1995), builds on the principle that people place a particularly high value on more scenic landscapes. Similarly, scenic quality is used as the main 


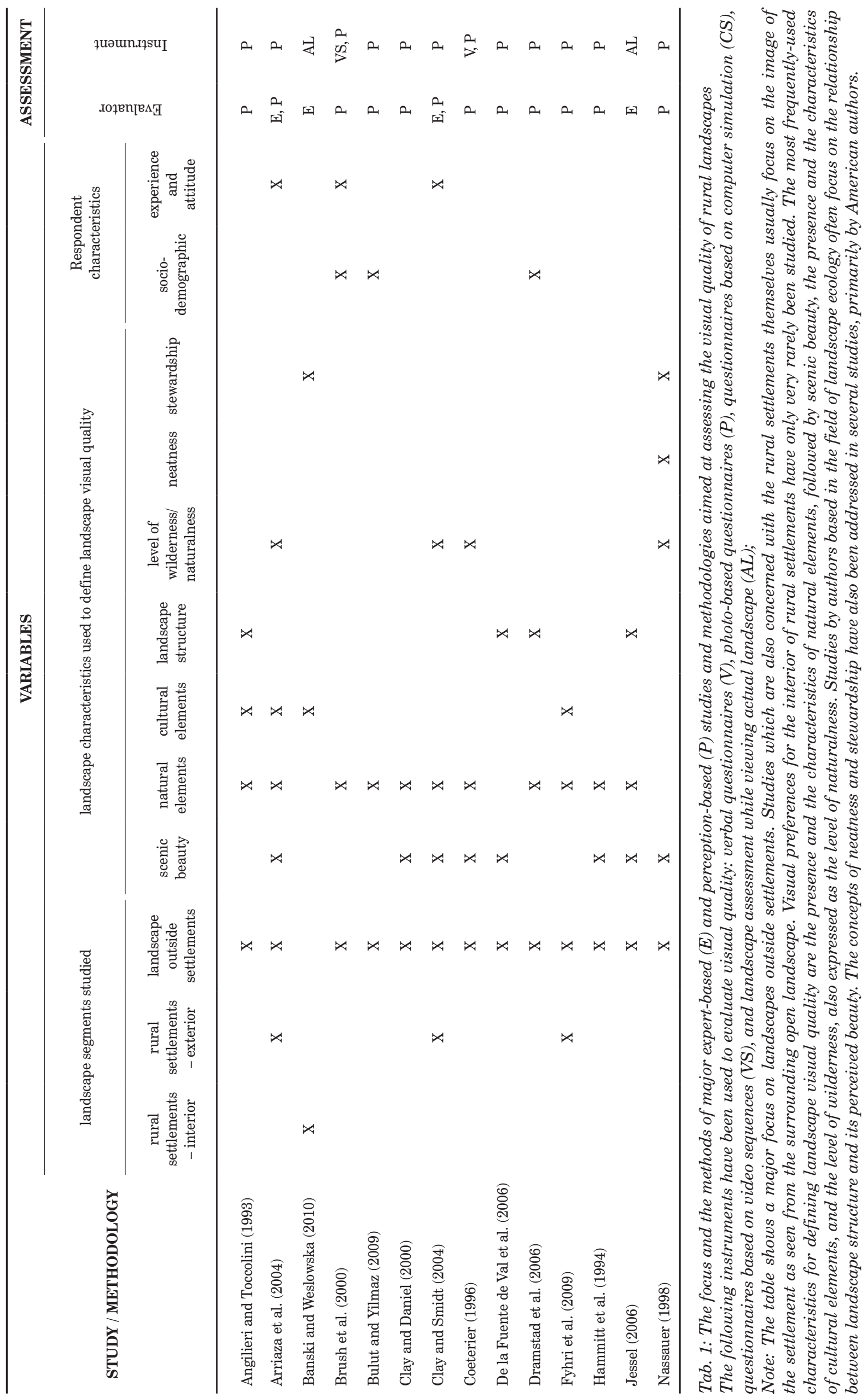




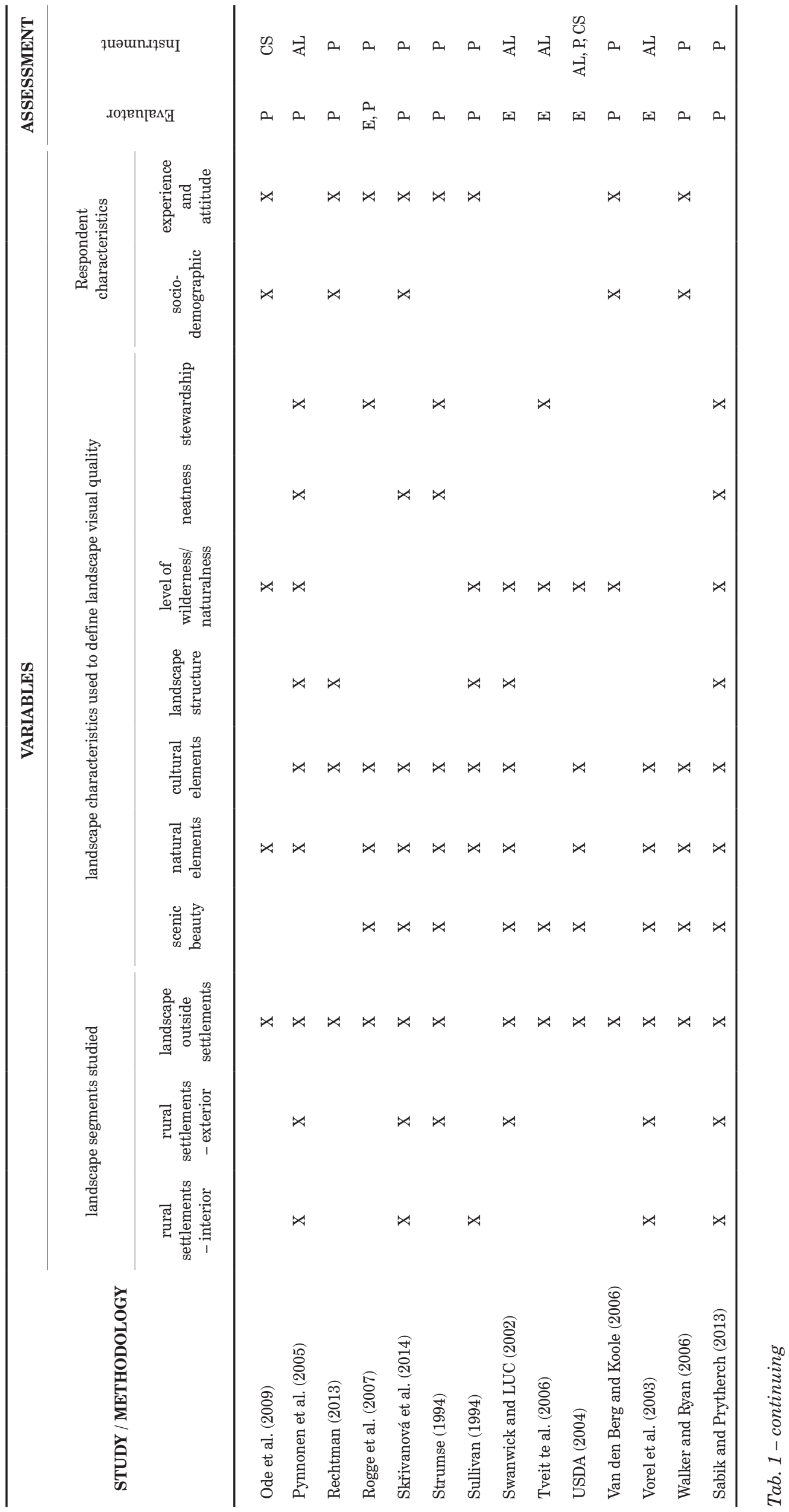


measure of aesthetic quality of the landscape in the method for assessing the visual impact on landscape character of proposed construction work or changes in land use (Vorel et al., 2003). Nassauer (1988), however, points out that while scenic beauty is an important aspect of landscape attractiveness, respondents also value apparent naturalness, neatness and conservation, especially in their local landscapes. In an article summarising aesthetic objectives relevant to agricultural policy, Nassauer (1989) accentuates the role of scenic quality, neatness and stewardship. The latter concept has become an important issue in the evaluation and protection of cultural landscapes. It has been reflected especially by American authors (Pynnonen et al., 2005; Strumse, 1994), but also in some recent European studies, e.g. by Sklenicka and Molnarova (2010) and by Tveit et al. (2006). The authors established nine key visual concepts for assessing the aesthetic qualities of landscape: stewardship, coherence, disturbance, historicity, visual scale, imageability, complexity, naturalness and ephemera.

Original studies concerning the visual aesthetic quality of open landscapes have become a central point of research interest (e.g. Angileri and Toccolini, 1993; Arriaza et al., 2004; Kaplan and Kaplan, 1982). As will be shown below, many authors have attempted to identify factors that have positive or negative impacts on the overall aesthetic effect of landscapes outside settlements. The landscape of rural settlements themselves, however, has been relatively neglected (Tab. 1).

Public attitudes toward landscapes outside settlements have been studied by a number of authors (e.g. Coeterier, 1996; Kaplan and Kaplan, 1982; Ode et al., 2009; Retchman, 2013). It has been found that the perception of these landscapes is strongly influenced by such elements as vegetation (Angileri and Toccolini, 1993; Swanwick, 2009), water elements (Bulut and Yilmaz, 2009; Dramstad et al., 2006; Hammitt et al., 1994) or meadows (Clay and Daniel, 2000), and also by the overall characteristics of the landscape. Clay and Smidt (2004) note that vividness, variety and unity are generally considered to be the most influential characteristics in this respect, while other authors have also emphasised openness (Rogge et al., 2007; Strumse, 1994), colour contrast (Arriaza et al., 2004), naturalness (Ode et al., 2009; Palmer, 2004; Van den Berg and Koole, 2006), typicality (Fyhri et al., 2009; Stamps and Nasar, 1997), or the age of structures (Tilt et al., 2007). Moreover, Svobodova et al. (2014) proved that landscape composition has a significant influence on visual preferences. According to Rogge et al. (2007) and Swannick (2009), for example, socio-demographic characteristics, such as age, profession, social and economic status or the environmental value orientations of the respondents, may also play an important role in shaping their visual perceptions of a landscape. As was noted above, little attention has been devoted to studies of visual preferences for rural settlement landscapes. While rural settlements are undoubtedly integral parts of rural landscapes (and at the same time they form landscapes of their own), research has mostly been focused on landscapes outside settlements. Where researchers have paid attention to rural settlements, they have studied them from the point of view of their architecture, and not as landscapes as such (Council of Europe, 2000). Moreover, respondents generally regard settlements as having the lowest aesthetic value (Stamps, 1994; Skřivanová et al., 2014). Nevertheless, settlements may be accorded relatively high preferences when they fit certain characteristics (Skřivanová et al., 2014), and for this reason they merit increased attention.
Nasar and Kang (1999) examined the aesthetic impacts of individual buildings, assessing 15 different architectural styles that are used in both urban and rural contexts in the USA. The results of the study show a preference for traditional forms across all studied groups. Similar conclusions have emerged from other studies, such as those by Stamps and Nasar (1997), Skřivanová et al. (2014), and Banski and Wesolowska (2010). In another study, Stamps (1994) examined the influence of context on aesthetic preferences. He concluded that the context is more important than the appearance of individual buildings, observing that buildings are better perceived in uniform contexts than in diverse contexts. Preference is shown for buildings that are adapted to their surroundings in terms of their scale and character. In the context of rural settlements, family houses are preferred (Sullivan, 1994). According to Sullivan, lot size and the presence of greenery are also important elements. Pynnonen et al. (2005) confirmed Sullivan's finding, stating that small lots are disturbing to rural character, while the presence of greenery helps integrate a new development into old structures. The importance of greenery was confirmed by Stamps (1997), who noted that the positive influence of greenery is greater than the negative influence of disturbing elements such as electricity wires or parked cars. Thorbeck (2012) notes the negative visual effect of animal housing barns and pole barns in the American rural landscape, as well as new patterns of residential development in these landscapes. Both of these phenomena are felt to lack visual connection to the character of the landscape.

In most preference-based studies on the visual quality of open landscapes, as well as rural settlements, respondent evaluations of the landscapes are based on photographs. In the European context, these photographs are often taken from vantage points, which are usually visited on foot. It is the underlying context of many European studies (Fyhri et al., 2009; Svobodova et al., 2012) and landscape assessment methodologies (Swanwick and Land use Consultants, 2002; Vorel et al., 2003) that people mostly appreciate the visual quality of a landscape while walking through it or engaging in other outdoor activities. In comparison, Nassauer (1989) notes: "the rural landscape is the primary setting for the most popular recreational activity, driving for pleasure" in the North American context. This phenomenon is illustrated for example by Clay and Smidt (2004) and by Brush et al. (2000), who have conducted a study on group differences in the enjoy-ability of driving through rural landscapes, using video recordings to assess respondents' preferences for forest, farm or urban edge landscapes. In this study, the higher appreciation of rural landscape by farmers than by other groups of respondents was linked to the farmers' better knowledge of the landscape and of the agricultural processes operating in this landscape. Studies by Ryan (2002) and Tilt et al. (2007) focused on defining the elements that contributed to the perception of areas affected by exurbanisation as rural areas, without specifically addressing the perceived visual quality of these elements. Both studies accentuate the role of natural features. Tilt et al. also note the importance of traditional building materials and lot sizes. Several studies (e.g. Arriaza et al., 2004; Kaplan et al., 2006) also link perceived rural identity, as well as preference for rural landscapes, to the presence of active agriculture in the area. In a study of abandoned agricultural landscapes, Hunziker (1995) found a preference for partially re-afforested landscapes, but this preference was linked to the higher diversity of the successional landscapes. Fjelstad and Dramstad (1999) noted that as these landscapes lose 
their diverse character when they are without management, their attractiveness for exurbanites and second-home owners might decrease.

In a literature review on the phenomenon of exurbia, Taylor (2011) states that the search for the "rural idyll" is a powerful factor in the residential decisions and conservationist activities of exurbanites. The presence of natural elements (Champion, 1998; Hart, 1995) and low residential density (Berube et al., 2006; Ryan, 2002) are the most widely discussed aspects of this concept. Zabik and Prytherch (2013) found that residents of landscapes affected by exurbanisation preferred "the more rugged, sparsely populated areas... characterised by large blocks of public and private forest land, narrow valleys, small streams and farmland... While most people preferred areas of farmland and forests, village landscapes were still highly valued".

In a study of visual preferences and place attachment in an exurban context, Walker and Ryan (2008) confirmed the high preference for natural elements and agricultural features, which were also found most important in forming place attachment. Cultural elements such as churches, cemeteries or dirt roads were generally found less attractive and less important, although long-term residents placed more value on these features than did newcomers. Importantly, Walker and Ryan (2008) found a strong correlation between the place attachment of residents and their support for conservation planning. In a similar study in the Central European context, Skřivanová et al. (2014) found a strong preference for both natural and cultural landmarks.

While these findings are important overall, they provide only a narrow background for discussing the visual aesthetic qualities of a rural settlement. This discussion is highly important for the effective regulation of exurban development. We need first to identify rural settlement values (Ryan, 2002), in order to find out which values are worth protecting and even expanding.

\section{Consensus in the perception of visual aesthetic qualities}

As mentioned above, the main goal of studies concerned with the visual quality of landscapes is to identify elements or overall characteristics that have a positive or negative impact on perceptions of the landscape (e.g. Angileri and Toccolini, 1993; Bulut and Yilmaz, 2009; Clay and Smidt, 2004). Since any practical application of the results of landscape preference studies implies that there should be agreement among individuals (Hägerhall, 2001), consensus in judgments of landscape visual qualities is highly important. Aesthetic values are considered to be an important aspect of the rural character of a landscape, so consensus on these values can provide a basis for protective measures. Purcell and Lamb (1984) point out that if consensus in judgments of landscape visual qualities did not exist, it would make the legal and decision-making process much more complex and more difficult. In this case, the visual qualities of a landscape would be merely subjective, and it would be hard to justify their use as a basis for protecting the landscape. Although many authors consider consensus to be a crucial issue (e.g. Hägerhall, 2001; Purcell and Lamb, 1984; Stamps and Nasar, 1997), and Daniel (2001) predicted a serious focus on consensus building efforts in future landscape management, only a few recent studies have focused on this topic.
In his essay, Kates (1967) presumed a significant consensus among respondents on what is ugly, whereas beauty was presumed to be a fleeting, elusive, individual and subjective value. He concluded that beauty and ugliness are not the two extremes of a single scale, but that they are on two independent scales. Unlike beauty, he considered ugliness to be objective and definable. Dearden (1981), however, regarded beauty and ugliness as opposite extremes of a single scale, and proved that the level of consensus in landscape evaluation grew with the increasing perceived beauty of a landscape. This conclusion was confirmed in a study by Kalivoda et al., (2014). In contrast, Purcell and Lamb (1984) came to the conclusion that the level of consensus is connected neither with beautiful landscapes nor with ugly landscapes. They found that a high level of consensus occurred in the evaluation of uncomplicated, conflict-free landscapes. Some examples of possible conflict described in this study were golf courses or uncultivated areas, which were evaluated differently by respondents according their knowledge and paradigms. On the other hand, Hägerhall (2001) came to the conclusion that consensus is significantly influenced by the mental image of a specific landscape type (the study used the example of pastures), and that the more a landscape scenery conforms to the idealised mental image of a given landscape type, the higher is the level of consensus in the evaluation of its visual qualities.

In addition, a limited number of studies have focused on the influence of demographic characteristics on the level of consensus in landscape evaluation. While Hägerhall (2001) concluded that these factors do not significantly influence consensus, Kalivoda et al. (2014) found significant differences in judgment consensus for all tested characteristics: gender, age, occupation, type of residence (urban, suburban, rural), and level of education.

\section{Conclusions}

We have endeavoured to outline the broad field of rural identity and its connection to landscape aesthetics. We have particularly focused on research from the United States and Western Europe, for two reasons. Firstly, as in Central Europe, large parts of these areas have a moderate climate and predominantly agricultural land use. Secondly, major socio-political and economic changes leading to an acceleration of the exurban settlement process occurred in these countries several decades earlier than they did in the post-socialist countries of Central Europe. Literature on landscape development relevant to rural identity which followed these changes can therefore provide useful insights into the current development of the present-day Central European landscapes.

The overview presented in this paper raises two important issues that need to be resolved. The first of these is the need to consider the visual aesthetic quality of rural settlements. Studies concerned with settlement aesthetics have usually been conducted by architects and from an architectural point of view. Rural and exurban settlements are distinct landscapes, however, and as such they should be examined by the same means as are open landscapes. Most landscapeoriented studies focus on open landscapes, while very little research has been done on the visual aesthetic quality of rural settlement landscapes.

Secondly, this overview has demonstrated the need to determine the principles of consensus formation in the field of landscape aesthetic quality, in general, and in the context 
of rural and exurban landscapes, in particular. This is crucial for consensus-building efforts and for establishing what is the nature of general public interest in protecting landscape aesthetic values.

These conclusions are particularly important today, when there is extreme pressure on rural identity, which is by its nature far from static. Rapid exurban development, in particular, often leads to the loss of specific environmental characteristics, depriving the society of a part of its cultural heritage. There is an urgent need to identify the values defining the character of rural settlements and their importance to stakeholder groups, in order to form a basis for making informed rural planning decisions and for preserving the most valuable aspects of the rural character of exurban landscapes.

\section{Acknowledgement}

This work was supported by the Norway Grant EHP-CZ02OV-1-027-2015 under the title: The Reduction of Habitat Fragmentation Consequences in Various Types of Landscape in the Czech Republic. The authors owe special thanks to Robin Healey for his useful advice.

\section{References:}

AN, L., BROWN, D. G., NASSAUER, J. I., LOW, B. (2011): Variations in development of exurban residential landscapes: Timing, location, and driving forces. Journal of Land Use Science, 6(1): 13-32.

ANGILERI, V., TOCCOLINI, A. (1993): The assessment of visual quality as a tool for the conservation of rural landscape diversity. Landscape and Urban Planning, 24: 105-112.

ARENDT, D., BRABEC, E., DODSON, H. L., REID, C. YARO, R. D. (1994): Rural by Design: Maintaining Small Town Character. Washington, D.C.: APA Planners Press.

ARRIAZA, M., CAŃAS-ORTEGA, J. F., CAŃAS-MADUEŃO, J.A., RUIZ-AVILES, P. (2004): Assessing the visual quality of rural landscapes. Landscape and Urban Planning, 69: 115-125.

BANSKI, J., WESOLOWSKA, M. (2010): Transformations in housing construction in rural areas of Poland's Lublin region-influence on the spatial settlement structure and landscape aesthetics. Landscape and Urban Planning, 94: $116-126$

BERUBE, A., SINDER, A., WILSON, J. H. FREY, W. H. (2006): Finding exurbia: America's fast-growing communities at the metropolitan fringe. Washington, D.C.: The Brookings Institution.

BOURASSA, S. C. (1988): Toward a Theory of Landscape Aesthetics. Landscape and Urban Planning, 15: 241-252.

BOURASSA, S. C. (1990): A Paradigm for Landscape Aesthetics. Environment and Behavior, 22: 787-812.

BRABEC, E. (2001): An evaluation of the effectiveness of cluster development in the town of Southampton, New York. Urban Ecosystems, 5(1): 27-47.

BRUSH, R., CHENOWETH, R. E., BARMAN, T. (2000): Group differences in the enjoyability of driving through rural landscapes. Landscape and Urban Planning, 47(1): 39-45.

BULUT, Z., YILMAZ, H. (2009): Determination of waterscape beauties through visual quality assessment method. Environmental Monitoring and Assessment, 154: 459-468.
CARRUTHERS, J. I., VIAS, A. C. (2005): Urban, Suburban, and Exurban Sprawl in the Rocky Mountain West: Evidence from Regional Adjustment Models. Journal of Regional Science, 45(1): 21-48.

CHAMPION, A. G. (1998): Studying counter-urbanization and the rural population turnaround. In: Boyle, P. and Halfacree, K. [eds.]: Migration into rural areas: Theories and issues (pp. 21-40). Sussex, John Wiley.

CLAY, G. R., DANIEL, T. C. (2000): Scenic landscape assessment: the effects of land management jurisdiction on public perception of scenic beauty. Landscape and Urban Planning, 49: 1-13.

CLAY, G. R., SMIDT, R. K. (2004): Assessing the validity and reliability of descriptor variables used in scenic highway analysis. Landscape and Urban Planning, 66: 239-255.

COETERIER, J. F. (1996): Dominant attributes in the perception and evaluation of the Dutch landscape. Landscape and Urban Planning, 34: 27-44.

COUNCIL OF EUROPE (2000): European Landscape Convention. Florence, Italy.

DANIEL, T. C. (2001): Whither scenic beauty? Visual landscape quality assessment in the $21^{\text {st }}$ century. Landscape and Urban Planning, 54: 267-281.

DE VAL DE LA FUENTE, G., ATAURI, A., DE LUCIO, J. C. (2006): Relationship between landscape visual attributes and spatial pattern indices: a test study in Mediterranean-climate landscape. Landscape and Urban Planning, 77: 393-407.

DEARDEN, P. (1981): Consensus and the landscape quality continuum: a research note, Landscape Research, 6: 31.

DRAMSTAD, W. E., TVEIT, M. S., FJELLSTAD, W. J., FRY, G. L. A. (2006): Relationships between visual landscape preferences and map-based indicators of landscape structure. Landscape and Urban Planning, 78: 465-474.

EBEN SALEH, M. A. (2001): Environmental cognition in the vernacular landscape: assessing the aesthetic quality of Al-Alkhalaf village, Southwestern Saudi Arabia. Building and Environment, 36: 965-979.

EWALD, K. C. (2001): The neglect of aesthetics in landscape planning in Switzerland. Landscape and Urban Planning, 54: 255-266.

FJELLSTAD, W. J., DRAMSTAD, W. E. (1999): Patterns of change in two contrasting Norwegian agricultural landscapes. Landscape and Urban Planning 45: 177-191.

FLORIDA, R., MELLANDER, C., STOLARICK, K. (2011): Beautiful Places: The Role of Perceived Aesthetic Beauty in Community Satisfaction. Regional Studies, 45: 33-48.

FOLEY, K., SCOTT, M. (2014): Accommodating new housing development in rural areas? Representations of landscape, land and rurality in Ireland. Landscape Research, 39(4): 359-386.

FRANTÁL, B., MALÝ, J., OUŘEDNÍČEK, M., NEMEŠKAL, J. (2016): Distance matters. Assessing socioeconomic impacts of the Dukovany nuclear power plant in the Czech Republic: Local perceptions and statistical evidence. Moravian Geographical Records, 21: 2-13.

FREDERICK, W. C. (2007): Nature and Business Ethics. In: Frederick, R. E. [ed.]: A Companion to Business Ethics (pp. 100-111). Pittsburgh: University of Pittsburgh. 
FYHRI, A., JACOBSEN, J. K. S., TŘMMERVIK, H. (2009): Tourists' landscape perceptions and preferences in a Scandinavian costal region. Landscape and Urban Planning, 91: 202-211.

GOSNELL, H., ABRAMS, J. (2011): Amenity migration: diverse conceptualization of drivers, socioeconomic dimensions, and emerging challenges. GeoJournal, 76: 303-322.

HÄGERHALL， C. M. (2001): Consensus in landscape preference judgements. Journal of Environmental Psychology: 21: 83-92.

HALLEUX, J. M., MARCINCZAK, S., VAN DER KRABBEN, E. (2012): The adaptive efficiency of land use planning measured by the control of urban sprawl. The cases of the Netherlands, Belgium and Poland. Land Use Policy, 29(4): 887-898.

HAMMITT, W. E., PATTERSON, M. E., NOE, F. P. (1994): Identifying and predicting visual preference of southern Appalachian forest recreation vistas. Landscape and Urban Planning, 29: 171-183.

HART, J. F. (1995): Rural and "farm" no longer mean the same. In: Castle, E. N. [ed.]: The changing American countryside (pp. 63-76). Lawrence, University of Kansas.

HART, J. F. (1998). The rural landscape. London: The John Hopkins University Press.

HOUFKOVÁ, P., BUMERL, J., POSPÍŠIL, L., KARLÍK, P., BENEŠ, J., BERNARDOVÁ, A., HRABALÍKOVÁ, M., JANEČKOVÁ MOLNÁROVÁ, K., HEJCMAN, M. (2015): Origin and development of long-strip field patterns: A case study of an abandoned medieval village in the Czech Republic. Catena, 135: 83-91.

HOWLEY, P., HYNES, S., DONOGHUE, C. O. (2012): Countryside preferences: Exploring individuals' willingness to pay for the conservation of the traditional farm landscape. Landscape Research, 37(6): 703-719.

HUNZIKER, M. (1995): The spontaneous reafforestation in abandoned agricultural lands: perception and aesthetic assessment by locals and tourists. Landscape and urban planning, 31(1): 399-410.

HURLEY, P.T., WALKER, P.A. (2004): Whose vision? Conspiracy theory and land-use planning in Nevada County, California. Environment and Planning A, 36(9): 1529-1547.

IHATSU, E. (2005): The attractive village - enhancing character and image as sources of local wealth (pp. 201203). The second international scientific conference: Rural development 2005, Proceedings 2. Kaunas, Lithuania.

JESSEL, B. (2006): Elements, characteristics and character - Information functions of landscapes in terms of indicators. Ecological Indicators, 6: 153-167.

JORGENSEN, A. (2011): Beyond the view: Future directions in landscape aesthetics research. Landscape and Urban Planning, 100: 353-355.

KALIVODA, O., VOJAR, J., SKŘIVANOVÁ, Z., ZAHRADNÍK, D. (2014): Consensus in landscape preference judgments: The effect of landscape visual aesthetic quality and respondent characteristics. Journal of Environmental Management 137: 36-44.

KAPLAN, S., KAPLAN, R. (1982): Cognition and Environment, Functioning in an uncertain world. New York, Praeger.
KAPLAN, A., TAŞKIN, T., ÖNENÇ, A. (2006): Assessing the visual quality of rural and urban-fringed landscapes surrounding livestock farms. Biosystems Engineering, 95(3): 437-448.

KATES, R.W. (1967): The pursuit of beauty in the environment. Landscape, 16: 21-25.

KURDOGLU, O., KURDOGLU, B. C. (2010): Determining recreational, scenic, and historical-cultural potentials of landscape features along a segment of the ancient Silk Road using factor analyzing. Environmental Monitoring and Assessment, 170: 99-116.

KUREK, S., WÓJTOWICZ, M., GAŁKA, J. (2015): The changing role of migration and natural increase in suburban population growth: The case of a non-capital post-socialist city (The Krakow Metropolitan Area, Poland). Moravian Geographical Reports, 23(4): 59-70.

LAGRO, J. A. (1994): Population growth beyond the urban fringe: implications for rural land use policy. Landscape and Urban Planning, 28(2): 143-158.

LAGRO JR, J. A. (1998): Landscape context of rural residential development in Southeastern Wisconsin (USA). Landscape Ecology, 13(2): 65-77.

LAPPING, M., DANIELS, T., KELLER, J. (1989): Rural Planning and Development in the United States. New York, The Guilford Press.

LITWIN, U., PLUTA, M. (2015): Spatial planning in Poland in years 1928-2003. Review and research of Acts records. Geomatics, Land management and Landscape, 4: 61-67.

LOTHIAN, A. (1999): Landscape and the philosophy of aesthetics: is landscape quality inherent in the landscape or in the eye of beholder? Landscape and Urban Planning, 44: 177-198.

LÖW, J., MÍCHAL, I. (2003): Krajinný ráz. Kostelec nad Černými Lesy, Lesnická práce.

MAIER, K. (1998): Czech planning in transition: Assets and deficiencies. International Planning Studies, 3(3): 351-365.

MARCOUILlER, D. W., LAPPING, M. B., FURUSETH, O. J. [eds.] (2011): Rural Housing, Exurbanization, and Amenity-driven Development: Contrasting the "Haves" and the "Have Nots". Farnham, Ashgate Publishing.

NASAR, J. L., KANG, J. (1999): House style preference and meanings across taste cultures. Landscape and Urban Planning, 44(1): 33-42.

NASSAUER, J. I. (1988): Landscape care: Perceptions of local people in landscape ecology and sustainable development. Landscape and Land Use Planning, 8: 27-41.

NASSAUER, J. I. (1989): Agricultural policy and aesthetic objectives. Journal of Soil and Water Conservation, 44(5): 384-387.

NASSAUER, J. I. (1995): Culture and changing landscape structure. Landscape Ecology, 10(4): 229-237.

NUGA, M., METSPALU, P., ORG, A., LEETMAA, K. (2015): Planning post-summurbia: From spontaneous pragmatism to collaborative planning? Moravian Geographical Reports, 23(4): 36-46.

NUSSL, H., RINK, D. (2005): The production of urban sprawl in Eastern Germany as a phenomenon of postsocialist transformation. Cities, 22: 123-134. 
ODE, A., FRY, G.,TVEIT, M. S., MESSAGER P., MILLER, D. (2009): Indicators of perceived naturalness as drivers of landscape preference. Journal of Environmental Management, 90: 375-383.

PALMER, J. F. (2004): Using spatial metrics to predict scenic perception in a changing landscape: Dennis, Massachusetts. Landscape and Urban Planning, 69: 201-218.

PALMER, J. F., HOFFMAN, R. E. (2001): Rating reliability and representation validity in scenic landscape assessments. Landscape and Urban Planning, 54: 149-161.

PÁNEK, J., TƯMA, O. (2009): A history of the Czech lands. Prague, Karolinum

PELTAN, T. (2012): Suburbanizace a energetická náročnost dojižd'ky. Urbanismus a územní rozvoj, 15: 21-26.

PURCELL, A. T., LAMB, R. J. (1984): Landscape perception: an examination and empirical investigation of two central issues in the area. Journal of Environmental Management, 19: 31-63.

PURCELL, A. T., NASAR, J. L. (1992): Experiencing other people's houses: a model of similarities and differences in environmental experience, Journal of Environmental Psychology, 12: 199-211.

PYNNONEN, D., PROPST, D., VOGT, C., MCDONOUGH, M. (2005): Role of natural and cultural features in residents' perceptions of rural character. In: Peden, J. G. and Schuster, R. M. [eds.]: Proceedings of the 2005 Northeastern Recreation Research Symposium. Newtown Square, Pennsylvania (pp. 32-38). USDA Forest Service, Northeastern Research Station.

RECHTMAN, O. (2013): Visual perception of agricultural cultivated landscapes: Key components as predictors for landscape preferences. Landscape Research, 38(3): 273-294

ROGGE, E., NEVENS, F., GULNICK, H. (2007): Perception of rural landscapes in Flanders: Looking beyond aesthetics. Landscape and Urban Planning, 82: 159-174.

RYAN, R. L. (2002): Preserving rural character in New England: local residents' perceptions of alternative residential development. Landscape and Urban Planning, 61: 19-35.

SKLENICKA, P., MOLNAROVA, K., BRABEC, E., KUMBLE, P., PITTNEROVA, B., PIXOVA, K., SALEK, M. (2009): Remnants of medieval field patterns in the Czech Republic: analysis of driving forces behind their disappearance with special attention to the role of hedgerows. Agriculture, ecosystems, environment, 129(4): 465-473.

SKLENICKA, P., JANOVSKA, V., SALEK, M., VLASAK, J., MOLNAROVA, K. (2014): The Farmland Rental Paradox: extreme land ownership fragmentation as a new form of land degradation. Land Use Policy, 38: 587-593.

SKLENICKA， P., MOLNAROVA, K. (2010): Visual perception of habitats adopted for post-mining landscape rehabilitation. Environmental management, 46(3): 424-435.

SKLENICKA, P., MOLNAROVA, K., PIXOVA, K. C., SALEK, M. E. (2013): Factors affecting farmland prices in the Czech Republic. Land Use Policy, 30(1): 130-136.
SKŘIVANOVÁ, Z., KALIVODA, O., SKLENIČKA, P. (2014): Driving factors for visual landscape preferences in protected landscape areas. Scientia Agriculturae Bohemica, 45: 36-43.

STAMPS, A. E. (1990): Use of photographs to stimulate environments. A meta-analysis. Perceptual and Motor Skills, 71(33): 907-913.

STAMPS, A.E. (1994): A study in scale and character: contextual effects on environmental preferences. Journal of Environmental Management, 42: 223-245.

STAMPS, A. E. (1997): Some streets of San Francisco: preference effects of trees, cars, wires, and buildings. Environment and Planning B: Planning and Design, 24: 81-93.

STAMPS, A. E., NASAR, J. L. (1997): Design review and public preferences: effects of geographical location, public consensus, sensation seeking, and architectural styles. Journal of Environmental Psychology, 17: 11-32.

STEWART, T. R., MIDDLETON, P., DOWNTON, M., ELY, D. (1984): Judgments of photographs vs. field observations in studies of perception and judgment of visual environment. Journal of Environmental Psychology, 4: 283-302.

STRUMSE, E. (1994): Environmental attributes and the prediction of visual preferences for agrarian landscapes in Western Norway. Journal of Environmental Psychology, 14: 293-303.

SULLIVAN, W. C. (1994): Perceptions of the rural-urban fringe: citizen preferences for natural and developed settings. Landscape and Urban Planning, 29: 85-101.

SVOBODOVA, K., SKLENICKA, P., MOLNAROVA, K., VOJAR, J. (2014): Does the composition of landscape photographs affect visual preferences? The rule of the Golden Section and the position of the horizon. Journal of Environmental Psychology, 38: 143-152.

SVOBODOVA, K., SKLENICKA, P., MOLNAROVA, K., SALEK, M. (2012): Visual preferences for physical attributes of mining and post-mining landscapes with respect to the sociodemographic characteristics of respondents. Ecological Engineering, 43: 34-44.

SWANWICK, C., LAND USE CONSULTANTS (2002): Landscape Character Assessment: Guidance for England and Scotland. Cheltenham, The Countryside Agency and Edinburgh: Scottish Natural Heritage.

SWANWICK, C. (2009): Society's attitudes to and preferences for land and landscape. Land Use Policy, 26: 62-75.

ŠPULEROVÁ, J., DOBROVODSKÁ, M., IZAKOVIČOVÁ, Z., KENDERESSY, P., ŠTEFUNKOVÁ, D., PETROVIČ, F. (2013): Developing a strategy for the protection of traditional agricultural landscapes based on a complex landscape-ecological evaluation (the case of a mountain landscape in Slovakia). Moravian Geographical Reports, 21(4): 15-26.

TAYLOR, L. (2011): No boundaries: exurbia and the study of contemporary urban dispersion. GeoJournal, 76: 323-339.

TILT, J. H., KEARNEY, A. R., BRADLEY, G. (2007): Understanding rural character: cognitive and visual perceptions. Landscape and Urban Planning, 81: 14-26.

THORBECK, D. (2012): Rural Design. A New Design Discipline. New York, Routledge. 
TVEIT, M. S., ODE, Å., FRY, G. (2006): Key concepts in a framework for analysing visual landscape character. Landscape Research 31(3): 229-255.

TVEIT, M. S. (2009): Indicators of visual scale as predictors of landscape preference; a comparison between groups. Journal of Environmental Management 90: 2882-2888.

U.S. DEPARTMENT OF AGRICULTURE (1995): Landscape Aesthetics, a Handbook for Scenery Management. U.S. Dept. of Agriculture, Forest Service, Washington D.C.

U.S. DEPARTMENT OF AGRICULTURE (2004): Measuring rurality: rural-urban continuum codes, Washington, D.C.: Economic research service, USDA.

VAN DEN BERG, A. E., KOOLE, S. L. (2006): New wilderness in the Netherlands: an investigation of visual preferences for nature development landscapes. Landscape and Urban Planning, 78: 362-372.
VOREL, I., BUKÁČEK, R., MATĚJKA, P., CULEK, M., SKLENIČKA, P. (2003): A method for assessing the visual impact on landscape character of proposed construction, activities or changes in land use. Prague, Nakladatelství Naděžda Skleničková.

WALKER, P., FORTMANN, L. (2003): Whose landscape? A political ecology of the 'exurban' Sierra. Cultural Geographies, 10(4): 469-491.

WALKER, A. J., RYAN, R. L. (2008): Place attachment and landscape preservation in rural New England: a Maine case study. Landscape and Urban Planning, 86: 141-152.

ZABIK, M. J., PRYTHERCH, D. L. (2013): Challenges to planning for rural character: A case study from exurban southern New England. Cities, 31: 186-196.

\section{Please cite this article as:}

JANEČKOVÁ MOLNÁROVÁ, K., SKŘIVANOVÁ Z., KALIVODA, O., SKLENIČKA P. (2017): Rural identity and landscape aesthetics in exurbia: Some issues to resolve from a Central European perspective. Moravian Geographical Reports, 25(1): 2-12. Doi: 10.1515/ mgr-2017-0001. 